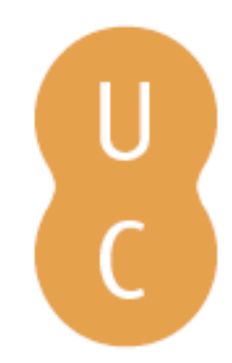

\title{
nommalina
}

\section{O valor epistemológico da História da História}
Autor(es):
Catroga, Fernando
Publicado por: Imprensa da Universidade de Coimbra
URL persistente:
URI:http://hdl.handle.net/10316.2/31570
DOI:
DOI:http://dx.doi.org/10.14195/978-989-26-0199-1_2
Accessed : $\quad$ 26-Apr-2023 12:51:55

A navegação consulta e descarregamento dos títulos inseridos nas Bibliotecas Digitais UC Digitalis, UC Pombalina e UC Impactum, pressupõem a aceitação plena e sem reservas dos Termos e Condições de Uso destas Bibliotecas Digitais, disponíveis em https://digitalis.uc.pt/pt-pt/termos.

Conforme exposto nos referidos Termos e Condições de Uso, o descarregamento de títulos de acesso restrito requer uma licença válida de autorização devendo o utilizador aceder ao(s) documento(s) a partir de um endereço de IP da instituição detentora da supramencionada licença.

Ao utilizador é apenas permitido o descarregamento para uso pessoal, pelo que o emprego do(s) título(s) descarregado(s) para outro fim, designadamente comercial, carece de autorização do respetivo autor ou editor da obra.

Na medida em que todas as obras da UC Digitalis se encontram protegidas pelo Código do Direito de Autor e Direitos Conexos e demais legislação aplicável, toda a cópia, parcial ou total, deste documento, nos casos em que é legalmente admitida, deverá conter ou fazer-se acompanhar por este aviso.

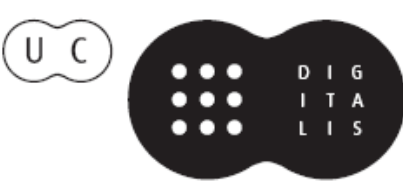


Maria Manuela Tavares Ribeiro

Coordenação

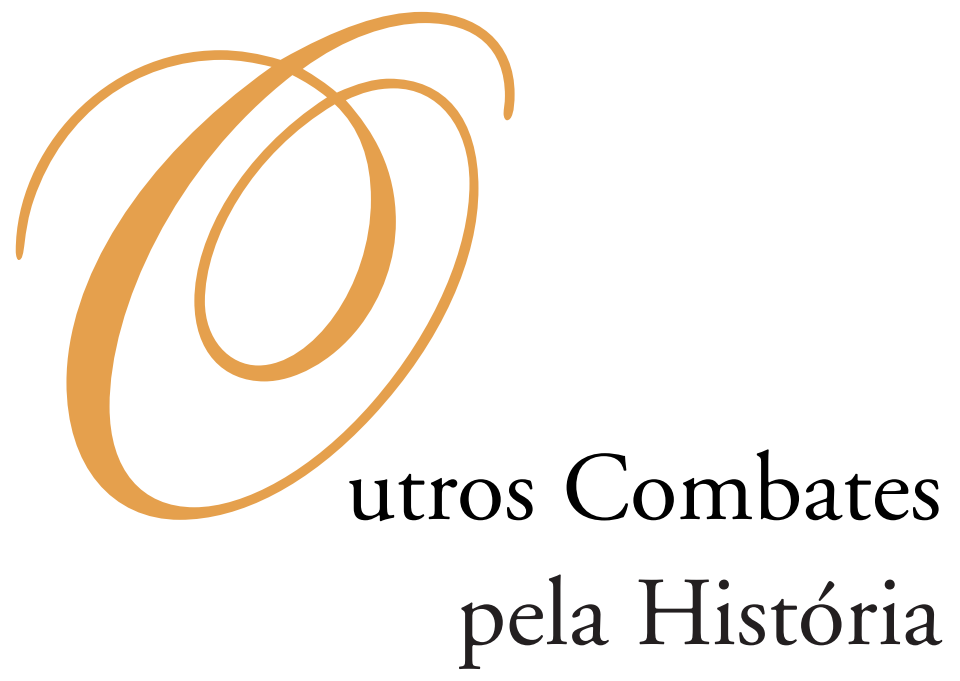




\section{COORDENAÇĀO EDITORIAL}

Imprensa da Universidade de Coimbra

Email: imprensauc@ci.uc.pt

URL: http://www.uc.pt/imprensa_uc

Vendas online: http://livrariadaimprensa.com

\section{CONCEPÇÃO GRÁFICA}

António Barros

\section{ORgANIZAÇĀO DOS TEXTOS}

Isabel Maria Luciano

Marlene Taveira

PRÉ-IMPRESSÃO

António Resende

Imprensa da Universidade de Coimbra

EXECUÇÃO GRÁFICA

SerSilito • Maia

ISBN

978-989-26-0041-3

DEPósito LEGAL

OBRA PUBLICADA COM O APOIO DE:

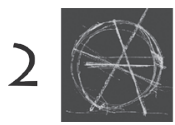

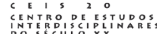

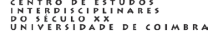

FCT Fundação para a Ciência e a Tecnologia

MINISTÉRIO DA CIÊNCIA, TECNOLOGIA E ENSINO SUPERIOR Portugal

Programa Operacional Ciência, Tecnologia, INOVAÇĀo DO QUADRo COMUNITÁRIO DE APOIO III

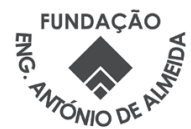

C JULHO 2010, IMPRENSA DA UNIVERSIDADE DE COIMBRA 
Maria Manuela Tavares Ribeiro

Coordenação

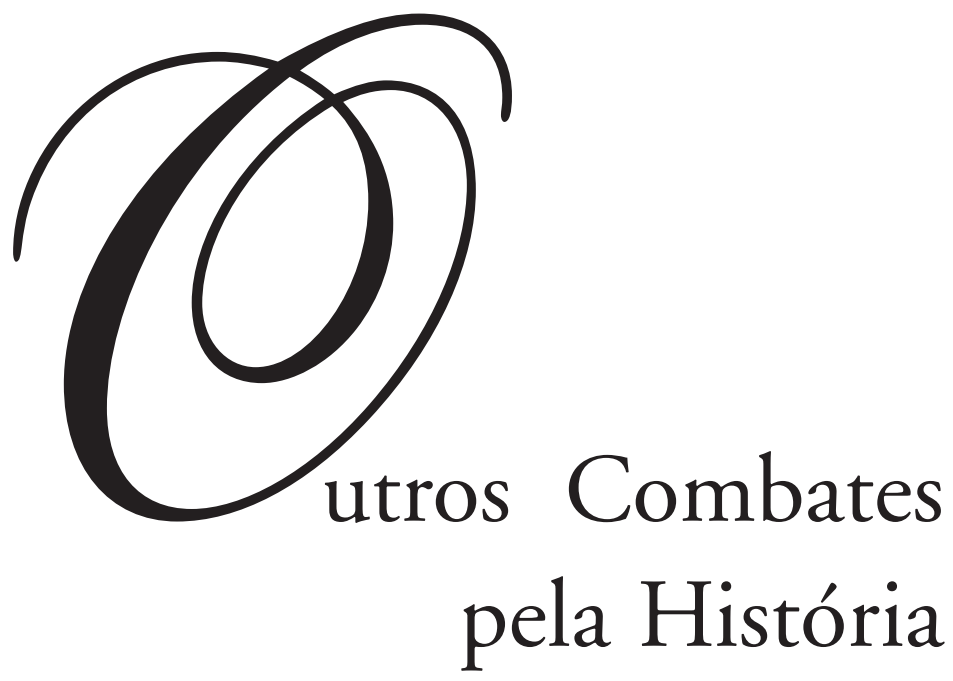

- colmbra 2010 
Outras Teorias da História 


\section{Fernando Catroga}

\section{O VALOR EPISTEMOLÓGICO DA HISTÓRIA DA HiSTÓRIA}

Não será erro afirmar que a historiografia moderna escolheu como seu interlocutor privilegiado o campo das ciências (naturais e, depois, sociais), em detrimento da teologia e das filosofias da história, criticando-lhes a pretensão de deduzirem a totalidade do percurso da história universal e o desejo de serem a voz do universal abstracto, no seio do qual o particular e o concreto não passariam de momentos ou mediações (ontológicas) da realização de um princípio-fundamento (um alfa), potência primordial que exigia o tempo para explicitar a plenitude da sua vocação ${ }^{1}$. Neste horizonte, o historiador estava condenado a ser o servidor da empiria que elas necessitavam para ilustrar as suas certezas, já que, incidindo o seu ofício sobre o factual e o mutável, ele não poderia nem ascender ao geral, nem compreender o sentido último do devir.

Será neste pano de fundo que se tem de situar as críticas que os historiadores desde Ranke e Alexandre Herculano, até Lucien Febvre — avançaram contra o império destas grandes narrativas. Em certa medida, eles propunham-se seguir o exemplo das demais ciências, cuja emancipação também se deu contra as filosofias que, antes, recobriam o seu objecto. Mas a força do fascínio pelo paradigma então mais credível (o das ciências da natureza), por parte da historiografia, aconselha a sublinhar-se uma outra evidência: a existência, nos historiadores, de um complexo de «inferioridade», cuja análise passa pela necessidade de se contextualizar a historicidade dos esforços para se autonomizar o seu campo epistémico.

Campo que, salvo honrosas excepçôes, não os tem preocupado muito. Ora, ao aderir-se ao princípio segundo o qual não há prática historiográfica sem teoria da história, também se terá de perceber que esta só será proficiente se os seus cultores ousarem problematizar o que e para que fazem. Inquietação que nunca será gratuita, porque, "para um historiador, pensar a relação entre as duas disciplinas [a filosofia e a história], é, antes de mais, colocar uma questão inteiramente prática e útil: em quê e como a reflexão filosófica permite elaborar melhor os problemas para os quais aponta, nos nossos dias, todo o trabalho histórico concreto e empírico?» (Roger Chartier, 1988).

\footnotetext{
${ }^{1}$ Inserimos este artigo em Os Passos do homem como restolho do tempo. Memória e fim do fim da história, Coimbra, Almedina, 2009.
} 
Responder cabalmente a este desafio equivale a mostrar a inadequação dos discursos normativos (enunciação externa daquilo que a historiografia deve ou não ser), ou exclusivamente explicativos (como se deve proceder tecnicamente com os documentos), e a indicar que continua em aberto todo um conjunto de temas (a delimitação dos objectos historiográficos, a narratividade, os critérios de validação) que tem de ser pensado, sob pena de a historiografia se confundir com o mais acéfalo (e mentiroso) dos empirismos. E, para que sejam abaladas muitas certezas - a maior parte das vezes aceites sem crítica, ou presunçosamente escudadas na ilusão de que o saber histórico se confunde com a erudição - , convoca-se os historiadores para um convívio proveitoso com a filosofia — não estamos a escrever, com a filosofia da história —, sugestão esta que incita a discutir-se a densidade cognitiva e a pertinência das técnicas historiográficas, dentro de um questionamento epistemológico mais amplo sobre as «relações existentes entre o discurso historiográfico e o referente que ele pretende reconstituir». Desiderato que, contudo, só será cumprido se houver disponibilidade intelectual para se elaborar, "filosoficamente, as dificuldades da prática histórica» (Roger Chartier, 1988), bem como abertura para se historicizar as da própria filosofia. $\mathrm{E}$, no que à sua quota-parte diz respeito, se os historiadores o não fizerem, outros o farão por eles.

\section{O historiador-epistemólogo}

Esta consequência será ainda mais nefasta se eles não se derem conta que o seu saber está sempre em debate, pelo que não lhes basta pôr em acção uma "preguiçosa", insciente (e inconsciente) «filosofia espontânea» da historiografia. E a pior das filosofias é a dos que proclamam a desnecessidade da atitude filosófica, como se a indagação do passado assentasse somente no fetiche do documento e no fetiche do método, e como se as suas conclusões fossem a mimesis do real ou uma mera racionalização do senso comum. No entanto, a saudável rejeição da filosofia da história por parte dos historiadores deixa um vazio que deve ser colmatado, não pelos seus sucedâneos ideológicos, mas por uma reflexão epistemológica que ajude a consciencializar o seu próprio trabalho e a inevitável historicidade deste, objectivo que, porém, não pode ser confundido com o da velha gnosiologia. E porquê?

É conhecido que esta tinha por função estudar a origem, estrutura e os limites de todas as formas de conhecimento. Dir-se-á que tal âmbito é comum ao que também se designa por filosofia da ciência, disciplina que, como registou Lalande (1968) no seu célebre Vocabulário filosófico, procede ao «estudo crítico dos princípios, das hipóteses e dos resultados das diversas ciências, com o fim de determinar a sua origem, a sua lógica, o seu valor e o seu grau de objectividade». Os limites desta caracterização são traçados pelo facto de ela referenciar mais a ciência feita do que a ciência em operação. O que pode manter a reflexão na exterioridade da prática do seu objecto, depositando nas mãos dos filósofos-epistemólogos, em exclusivo, o direito a declararem, de fora, o que é que deve ser a historiografia. Ora, o historiador deve sentir que tem alguma coisa a dizer sobre todas as matérias que mais directamente lhe dizem respeito. 
Sublinhe-se que correntes filosóficas marcantes, mormente as de inspiração neokantiana e hermenêutica, também puseram em causa as filosofias da história. Todavia, por maior que tenha sido a utilidade das suas críticas, a sua perspectiva focou, sobretudo, a analítica dos processos lógicos subjacentes ao conhecimento e menos as suas implicaçôes crono-lógicas. E deve lembrar-se que, quando a reflexão é muito externa, ela chega sempre demasiadamente tarde à prática que quer fundamentar. Por conseguinte, aconselha-se a epistemologia do historiador a estar em sintonia com a própria operação historiográfica e não ser uma espécie de prova póstuma da sua consciência teórica.

O cumprimento deste desiderato não pode significar, porém, surdez perante os juízos normativos de origem externa. Bem pelo contrário. Ele tem de ser confrontado com uma permanente abertura às controvérsias sobre o conhecimento e as ciências em geral, em ordem a que a historiografia, no seu terreno próprio, possa compartilhar algo que é comum a todas elas: o incentivo à problematização. Atitude que, para ser criadora, terá de estar enraizado numa cultura crítica (e auto-crítica) que possibilite a análise das sobredeterminações exteriores e interiores que se juntam no métier do historiador, embora este também deva saber que, em últimas instâncias, será o juízo dos outros (o leitor e, depois, o da história da historiografia) que melhor poderá surpreender aquilo de que ele se esqueceu, ou não conseguiu controlar através da razão, ou que, conscientemente, quis mesmo esconder.

Nesta ordem de ideias, terá de dialogar, quer com as teorias (explícitas ou implícitas) dos outros historiadores, quer com a vasta literatura de orientação epistemológica, em particular com a respeitante às ciências sociais. Só assim poderá lançar um «olhar» simultaneamente externo e interno (Gaston Bachelard, s.d.) sobre o seu trabalho e assumir algo que algumas reflexões sobre as ciências (Canguilhem, Thomas Khun e outros) há muito destacaram: a historiografia, tal como as outras produçôes de conhecimento científico (Hanson, Toulmin, Feyerband), são construções inscritas em «sistemas culturais» mais amplos (P. Rossi, 1986; Y. Elkana, 1979). O que, transportado para o seu terreno específico, ajudará a demarcar o que é próprio da "operação historiográfica» (qualificação avançada por Michel de Certeau e que Paul Ricœur virá a recuperar).

Será abusivo deduzir-se, contudo, que só será um óptimo historiador o que, ao mesmo tempo, for um competente epistemólogo. Mas é igualmente verdade que toda a boa historiografia - a que provocou influências renovadoras no seu domínio contém, nas obras que lhe dão corpo (de um modo assumido, ou, tão-só, praticado) uma epistemologia que, não raro, os seus autores explicitam no próprio texto, ou em ensaios teóricos que, muitas vezes a posteriori, ajudam a inteligir os seus fundamentos. Logo, não será por acaso que se encontram grandes historiadores a escrever sobre teoria da história, incluindo a que praticam. Daí, o crescimento recente de reflexôes sobre a «historiografia» e o da tendência para se articular, ou quase fundir, a história da história com a epistemologia. No entanto, também surgiram significativas reacções que importa sintetizar (François Hartog, 2005).

Comece-se por uma das mais antigas: a de Pierre Chaunu. Em 1960, entusiasmado com a cientificidade que o uso do método quantitativo traria à historiografia, atacou as preocupações teóricas que começavam a manifestar-se no seio dos seus pares, críticas que não deixavam de pôr em prática, igualmente, uma dada posição epistémica. E sintoma de que este tipo de atitude não se extinguiu foi o mais recente 
diagnóstico de G. Noiriel (1996), ao acusar os historiadores de estarem a agarrar-se à teoria como uma espécie de "fuga para a frente», a fim de escamotearem a "crise» da própria historiografia. Dando conta destas indagações, Antoine Prost, nas suas Douze lections sur l'histoire (1996), registou que «uma das evoluçôes recentes mais significativa da disciplina em França foi o interesse crescente pela reflexão epistemológica», e, ultimamente, François Hartog perguntou se, "depois do historiador como artesão», não se teria entrado na época do «historiador como epistemólogo» (F. Hartog, 2005).

Tem de se reconhecer, contudo, e como avisou Max Weber, que as preocupações exclusivamente epistemológicas e metodológicas não são decisivas, só por si, para se desbloquear o progresso das ciências, embora a pertinência do seu uso pareça aumentar nos períodos em que crescem as dúvidas acerca da natureza e da função daquelas. E a sua necessidade e importância serão tanto maiores quanto mais significativos são os sinais de crise, os quais, porém, também são, como já os gregos sabiam, momentos de suscitação da crítica (R. Koselleck, 1999), sendo útil que se convide o historiador à reflexão, de molde a consolidar-se a identidade mínima do seu do campo historiográfico, terreno com fronteiras mutantes e sempre ameaçadas pela absorção e invasão de outros e, em particular, daqueles com quem ele mantém mais afinidades. Com efeito, tem-se por certo que a prática teórica da historiografia ficará mais rica se souber mesclar a epistemologia com a operação que visa explicar/compreender o passado (François Hartog, 2005), e não separá-las, como algum pós-modernismo pretende, com a redução da historiografia à questão exclusivamente formal da sua escrita.

Será anacrónico, portanto, confundir-se este género de problematização com o praticado por aqueles a que, de um modo depreciativo, Lucien Febvre chamou «metodologistas impenitentes». Estes, nunca compreenderão que o método é, literalmente, caminho, itinerário indissociável da "operação historiográfica» que o dita e que, por isso, o cola ao problema e ao resultado da própria investigação. E tanto a sobrevalorização como a separação dos vários componentes que entram no historiar podem contribuir, ainda que involuntariamente, para o enfraquecimento da sua sustentabilidade epistémica. Por isso, aquele tem de ser pensado como um todo em acção, cujas partes só por razões analíticas e descritivas poderão ser cindidas.

\section{A lição da história da historiografia}

Num outro registo, o intercâmbio da vigilância epistemológica externa com a interna aconselha a fazer-se a retrospectiva crítica (e auto-crítica) do resultado do trabalho dos historiadores, elegendo-o como o objecto de um ramo historiográfico próprio. No fundo, põe-se em prática esta evidência: se toda a acção humana é histórica (e historiável), porque não o serão os tentames cognitivos para se apreender essa condicionalidade? Todo o trabalho historiográfico tem de ser pensado como uma actividade epocal, desencadeada a partir de horizontes de pré-compreensão, húmus de onde emergem os problemas a historiografar propriamente ditos. E estes, como os de todas as outras formas de saber, só podem nascer de inquietações intelectuais traduzíveis em questionários investigáveis, isto é, em perguntas conducentes a respostas capazes de alcançarem um mínimo de comprovação. 
Esta posição também não está desligada da dos outros discursos com objectivos científicos e, em primeiro lugar, dos que ocupam ou encobrem o objecto da historiografia. E, por mais desnecessário que possa parecer, será útil frisar que só os historiadores (profissionais ou não, pouco importa) põem problemas historiográficos, tanto mais que nem os factos são marcos do tempo com uma génese espontânea, nem os vestígios dos antepassados são inquiridos por mentes vazias como tábuas rasas. É que, como revela a história da historiografia, pôr questóes e fazer interpretaçôes arrastam consigo a problematização do já investigado nas áreas afins ao que se visa estudar. Pelo que não será excessivo concluir-se que o historiar implica fazer interpretações de interpretaçôes, característica plasmada no carácter decisivo das fontes e na bibliografia activa e passiva consultada.

Atrás já se registou esta convicção: se, tradicionalmente, a utilidade da história residia no seu magistério (historia magistra vitae), ou, em termos mais modernos, decorria da certeza de que o conhecimento do passado ajudava a compreender o presente, a fim de melhor se realizar o futuro, comummente se olvida que o contrário também é verdadeiro, pois, sendo a leitura do já ocorrido uma re-presentificação, porque edificada a partir do "presente», isso equivale a confessar que, afinal, a vida também é a grande mestra da história. Para isso, ela não pode ser confundida com o tempo real e, muito menos, com a sua banalização como eterno presente.

Sabe-se que o movimento intelectual que liga o renovamento das indagações às experiências do tempo que as provoca, e que tem denunciado a sobrevalorização do tempo real (ilusão de um presente eterno), em detrimento do presente real, aplicou o crivo da sua crítica à ideia segundo a qual será sempre o mesmo presente (assim postulado como um eterno presente, isto é, como um fim da história) a renovar as hermenêuticas do passado. É certo que, hoje, estas já não podem ser feitas à luz do que se julgava ser o desfecho inexorável do sentido do tempo histórico. Contudo, como poderá um eterno presente distinguir-se do passado, que reifica, sem simultaneamente se posicionar como futuro (definitivo) desse passado, prova evidente da sua insuficiência como realidade eterna?

Dito de outro modo: só o presente (ou melhor, o presente-passado e o presente-futuro) pode interrogar os vestígios do que está morto e espoletar os problemas historiográficos. Por outro lado, como se reivindica que tudo o que, consciente ou inconscientemente, foi deixado pelo homem interessa ao historiador, será uma contradição silenciar a historicidade das representações construídas a partir dos sinais deixados pelo passado, já que, ao contrário da ilusão hegeliana, seria ilógico que o historiador se julgasse situado num não-lugar e num não-tempo. A raiz ôntico-existencial da história da historiografia radica, precisamente, no facto de a existência humana ser o "trespassamento do tempo", pelo que, e como sublinhou Paul Ricœur, o homem faz e narra histórias, porque «nós somos históricos» (Paul Ricœur, 2000). Tese bem captada por esta asserção de Umberto Eco: «ser um animal político é ser, para o homem, um modo de ajustar contas com a sua própria morte». Como poderia a historiografia fugir à sua historicidade? Mesmo afirmar que ela é «a ciência do homem no tempo" (Marc Bloch, 1960), obriga a reconhecer-se que esta última categoria da definição sobredetermina, desde logo, não só a historicidade dos conceitos de "ciência» e de "homem» (ou de «homens»), mas também de «tempo», pois também existe uma história das representações do tempo histórico. 
«Ver» para além do «olhar»

Vários termos têm sido avançados para definir o processo do conhecimento do passado: «ofício», "trabalho», "operação», entre outros. Sublinhar-se-á esta última designação, pois as teorizações de Michel de Certeau, aprofundadas por Paul Ricœur, contêm achegas que podem ajudar a inteligir melhor as múltiplas facetas do trabalho do historiador, nem que para isso se separe, o que, na prática, constitui um processo em que todas as partes reciprocamente se requerem. Com tal objectivo, seguir-se-á este conselho de Michel de Certeau (1975): «perspectivar a história como uma operação, será tentar, de um modo necessariamente limitado, compreender como é que se dá a relação entre um lugar (um recrutamento, um meio, um ofício), os processos de análise (uma disciplina) e a construção de um texto». De facto, a produção de conhecimentos sobre o passado impõe a presença: de um sujeito epistémico, histórica e socialmente situado no espaço e no tempo; de um texto (toda a investigação culmina numa narração); e de destinatários deste (os receptores). E todas as características se vão realizando a partir de uma problemática que vai sendo posta à prova em três níveis fundamentais: o documental, o explicativo/compreensivo (ou interpretativo) e o da escrita, porque a realidade do discurso também faz parte do discurso sobre a realidade.

\section{A mediatês do conhecimento histórico}

Tudo isto ajuda a perceber, mais cabalmente, por que é que o conhecimento historiográfico é um saber mediato, expressão aqui usada como contraposição às ilusões perceptivistas e miméticas, tanto mais que, como se assinalou, mesmo Heródoto, não só inquiria e investigava, mas também, como o aedo, anunciava e revelava, mormente quando a realidade referenciada se afastava do visto pelo historiador.

As transformaçôes ocorridas no modo ocidental de se entender o mundo e a vida fizeram com que as narrações sobre o próprio passado se fossem distanciando, cada vez mais, da tutela da percepção. Em termos muito sintéticos, poder-se-á afirmar que se consolidou a não confusão entre a res gestae (plano ontológico) e a historia rerum gestarum (plano epistemológico), e que, no último século, se caminhou para o entendimento do objecto a historiar como um constructo da própria operação historiográfica, inconfundível com o «real». Isto é: compreendeu-se, de uma maneira mais inequívoca, que o "objecto" é um conceito epistemológico indissociável do processo que, activado pelo "questionário", o vai definindo em referência a acontecimentos indirectamente inferíveis a partir dos traços, vindos do esquecimento de reserva do passado e que remetem para quando este foi um presente-passado e um presente-futuro. Em tal horizonte, a chamada imaginação histórica (Collingwood) é voo que se despede do peso da imagem.

Como o historiador trabalha sobre sinais - que, como sublinhou Lévinas, implicam sempre um lugar histórico —, o fetiche do documento ficará mais desconstruído se, quer os conceitos de traço e de documento, quer os de acontecimento e facto histórico não forem definidos como sinónimos, pois, quando tal se dá, não se faz a devida distinção entre o plano ontológico e o epistémico. E este último coloca o documento 
e o facto histórico como produtos da própria operação historiográfica, ou melhor, da instância que a põe em movimento, a saber: o problema. Óptica que também nos ensina que, se todo o documento é um traço, nem todo o traço é, só por si, um documento, mormente quando, como esquecimento irreversivel, é nada. O traço só será documento quando for interrogado em termos historiográficos. Antes disso, pode ser «olhado», mas não «visto» como um testemunho do passado (provam-no, por exemplo, as gravuras de Foz-Côa, vestígios que, durante séculos, foram encarados por muitos, mas somente lidos como documentos quando perguntados na linguagem adequada: a dos arqueólogos). De certo modo, poder-se-á mesmo avançar com esta ideia: na sua acepção epistemológica, é o questionário (ou melhor, a operação historiográfica no seu todo) que «inventa» as fontes.

Sendo assim, tem de se concordar com a posição dos que têm denunciado os malefícios da fetichização dos documentos. Se é indiscutível que não haverá historiografia sem estes, é igualmente certo que eles nem são a realidade histórica (limitam-se a indiciá-la), nem falam se não forem interrogados. E a primeira condição para serem credíveis sustentáculos de um trabalho veritativo é resistirem à prova popperiana da falsificabilidade, afinal, na analítica Ricœur-Michel de Certau, o fundamental nível «arquivístico» da operação historiográfica. E nele se pode encontrar a condensação da longa herança que vem desde a autopsia de Tucídides, do comparativismo crítico do método histórico-filológico dos humanistas, das regras codificadas por Mabillon e por todos os bolandistas, até se chegar à sua recepção na historiografia alemã do século XIX e à sistematização "cartesiana" em Langlois e Seignobos.

Por outro lado, se nem todo o traço ascende a documento, também nem toda a historiografia se faz somente com documentos. Porém, ela não pode ser feita sem eles, desde que estejam fiabilizados pela crítica interna e externa, preceito metodológico antigo, mas ainda válido como arte da suspeita, quando adaptado às novas tecnologias da certificação, assim como ao correlato alargamento do seu próprio conceito. E, por mais autónomas que estas operações possam parecer, elas têm muito a ver com o papel matricial do questionamento na investigação, pois só por ele a fonte deixará de ser uma espécie de matéria inerte, ou arquivista, e passará a responder como uma «voz» que vem do passado.

O novo historiador, lendo o explícito ou implícito, o declarado ou silenciado, o afirmado ou o proibido, o incluído ou o excluído, o objectivado ou o lacunar, define, no interior do corpo documental, unidades, conjuntos, séries, relações, cuja construção, porém, não lhe é somente acessível através da heurística e da hermenêutica tradicionais. Por exemplo, se continua a ser necessário distinguir um documento «verdadeiro» de um "falso», é também importante tratar o "falso» como documento acreditado como "verdadeiro» no período que o produziu (Jorge Lozano, 1994). E certas correntes historiográficas como a micro-história, na linha do que Humboldt já tinha alvitrado, reivindicam mesmo a utilidade de se recorrer a métodos indiciários

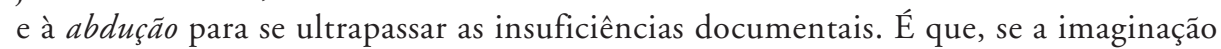
historiográfica é instância criadora de problemas comprováveis — necessidade que, depois de Collingwood (1935) e outros, historiadores «analistas» como Georges Duby (1991) enfatizaram — , ela tem de imediatamente estar presente na formulação de hipóteses plausíveis em função do que indubitavelmente se conhece. Outra maneira de afirmar que, logo no início da investigação, a imaginação historiográfica brota como atitude crítica da mimesis da representação. 
Pode dizer-se que o traço passa a documento quando começa a ser historiograficamente inquirido. Logo, ele é inseparável da problemática que, numa permanente negociação, norteia a operação historiográfica, interrogatório que, mediado pela finalidade de explicar e compreender, o põe a fornecer informações passíveis de serem comparadas. De certo modo, funciona como a "matéria-prima» — e não como «matéria bruta" - da interpretação. E é no processo de elevação do traço a documento que o acontecido (nível ontológico) se transmuda, em termos epistemológicos, em facto histórico.

Facilmente se aceita que nem todos os acontecimentos ascendem ao estatuto de "históricos», mormente aqueles sobre os quais existe uma ignorância total. Dir-se-ia que eles são o irreversível, ou, então, os cadáveres insepultos da história. Mas também se percebe que, no plano epistémico, um facto pode ser uma síntese que referencia milhares de acontecimentos. Assim, quantos destes não são convocados quando se ouve ou lê a expressão "Revolução Francesa de 1789»? Pelo que não será arrojado avançar-se com esta outra hipótese: um facto histórico (não confundir com o seu referente) só existe dentro da operação historiográfica, cabendo à base documental dar-lhe o suporte de referencialidade, de rectificação e de prova, requisitos deontológicos não exigíveis para as obras de ficção, incluindo as que parasitam o discurso historiográfico (como é o caso do chamado romance histórico, cujos efeitos de verosimilhança podem chegar até à citação de fontes credíveis). Como quem diz: a imaginação do historiador põe em funcionamento um processo criativo, mas aceita o controlo da crítica e da comprovação.

Não por acaso, é no patamar mais arquivístico e mais explicativo da operação que reside o nível cognitivo com maior capacidade para gerar consensos. Percebe-se. Assente na fiabilidade do documento e da consequente inferição e correlação (dominantemente "cronológica») dos «factos», e ainda sendo mínima a carga interpretativa, nesse degrau, o conhecimento está marcado por uma objectividade que, não só possibilita pensar-se que a historiografia só progride por acumulação, como parece dispensar o papel activo do sujeito-historiador, não obstante se saiba que já está presente na escolha, explícita ou implícita, do tema em análise.

Em concomitância, o reconhecimento da geminação do problema com o documento abre as portas à revisitação de uma outra ideia, de origem "positivista", mas durante muito tempo acreditada: a crença na esgotabilidade das fontes. Diga-se que ela medrou quando estas se cingiam, sobretudo, à sua faceta escrita e se escamoteava vários condicionantes "presentistas» do trabalho do historiador, particularmente a influência do questionário na metamorfose de vestígios em documentos, e a possibilidade de aquele ser movido pelo renovamento da imaginação historiográfica, mesmo nos casos em que a sua «matéria-prima» seja formada por «documentos» já conhecidos. Provar interpretações novas a partir de documentos conhecidos é tão difícil como trazer novidades suscitadas por vestígios até ai desconhecidos.

Aceita-se que a mera interligação dos vários níveis do trabalho a que Certeau chamou "operação historiográfica», ao tornar dependentes do problema tanto o documento como o facto histórico, é igualmente incompatível com a fetichização do método. E frisou-se que Lucien Febvre, alvejando directamente a historiografia "positivista», se distanciava daqueles para quem as questôes teóricas da historiografia se reduziam à questão metodológica, comummente limitada à crítica documental. 
Mas esse anátema não põe em causa a necessidade de se recorrer, para a credibilização do conhecimento histórico, às velhas «heurística» e "hermenêutica», embora se reconheça que elas terão de ser reactualizadas devido ao hodierno alargamento do conceito de documento e da capacidade tecnológica para se rectificar — prática tão necessária à investigação - a sua fiabilidade.

Ao dar-se peso ao problema, deseja-se frisar que o debate contém outras implicações (e aplicações), porque a sua sobredeterminação impóe a variedade dos «caminhos» que terão de ser trilhados para se demonstrar a sua pertinência. De onde os métodos correctos serem aqueles que mais convincentemente conseguirem levar a bom porto a comprovação do que se pretende demonstrar. Por outras palavras: a sua escolha não pode ser uma exclusiva opção apriorística, nem ser comparada ao uso de uma mera ferramenta, isto é, a algo exterior, como se se tratasse de uma ida a um pronto-a-vestir, ou de um casaco comprado em loja de roupa usada, sem se cuidar do corpo a que ele vai dar forma e conteúdo. Lá bem fundo, também na historiografia o caminho se faz caminhando e a justeza do rumo escolhido só no fim do percurso poderá ser cabalmente avaliada.

Quer isto significar que o método não é de senda única e universal, quando muito bifurcado pelas distintas onticidades do referente (natureza; sociedade) que marcariam um intransponível dualismo entre o explicar e o compreender. Para além do trabalho metodológico inerente à certificação documental e à consequente extracção dos factos, as escolhas, porque condicionadas pela índole do questionário, não podem estar metafisicamente pré-determinadas, sendo insensíveis às questôes concretas de espaço e de tempo, isto é, de conteúdo. Deve haver liberdade de se deitar mãos a todos os «métodos», qualquer que seja a sua proveniência original, desde que eles possam servir para se testificar a validade das hipóteses. É que só o cariz dominantemente retrospectivo da análise distingue a historiografia das demais ciências sociais. E todas são ciências do homem, pois, como se sabe, nem as chamadas ciências exactas escapam às condicionalidades históricas da sua produção. Pelo que as asas do historiador, tal como as desse pássaro sem eira nem beira, o cuco, devem ser livres para o levarem a chocar os ovos dos ninhos que possam trazer futuros ao passado.

\section{Explicar/compreender}

Quanto à existência de um dualismo cognitivo, há muito que uma corrente forte tinha procurado, pelo menos desde Vico, Droysen e Dilthey, fundamentar uma via autónoma para as ciências do espírito (Gemeinschaften), demarcando-a do nomotetismo universalista típico da exaltação do paradigma clássico das ciências da natureza. E o tratamento mais teorético deste debate também passa pela contextualização do aparecimento das teses hermenêuticas, considerando-a fundamental para o entendimento de todas as facetas da polémica acerca dos liames que existem entre explicação e compreensão. Vertente que conduz a um outro problema básico na reflexão epistemológica e sem o qual não se poderá tomar posição no tocante aos limites da verdade historiográfica. Referimo-nos à maneira como têm sido pensadas as relaçôes com as ciências da natureza e com as demais ciências sociais. O que, traduzido em termos epistémicos, consente o seu agrupamento em três atitudes nucleares (Elena Hernández Sandoica, 1995, 2004). 
A primeira, protagonizada pelo historicismo hermenêutico, definiu-se em competição com as ciências da natureza e reivindicou, para a historiografia, um método autónomo (qualitativo). Por isso, negou a possibilidade de serem formuladas leis e defendeu a inevitável presença da mediação de «valores» na interpretação, contrapondo à universalidade daquelas a singularidade e a fluxibilidade irredutível da realidade humana.

A segunda, pode ser designada por ciência-paradigma, porque enfatiza um modelo aplicável a todas as áreas do conhecimento. Este foi, durante muito tempo, o das ciências da natureza. Porém, em épocas mais recentes, são detectáveis "ondas» (para alguns, autênticas modas intelectuais) em que certas ciências humanas e sociais foram invocadas como sendo o "paradigma» das ciências do homem no seu conjunto. Depois do naturalismo, o psicologismo, o sociologismo, o etnologismo têm sido, com tempos e com intensidades diferentes, algumas das expressões da história recente desta tendência.

Finalmente, a terceira corrente caracteriza-se por propor o fomento de práticas inter e transdisciplinares aconselhadas pela existência da circularidade epistemológica, ao mostrar que as ciências humanas fazem parte de um sistema de saberes em que, ao contrário da unilinear e fechada taxinomia comtiana, são fundamentais, constantes e inerentes ao próprio processo de conhecimento as interacções e interdependências entre as várias ciências e respectivos métodos.

Como projecto, esta última tem provocado efeitos renovadores e com capacidade de resposta aos desafios do presente sempre em aberto, pois situa a historiografia num cruzamento epistemológico, sem correr riscos de diluição. Valorizar esta atitude, equivale a acolher os ensinamentos dos que, como Fernand Braudel, a puseram no lugar de "placa giratória» entre as várias ciências sociais, a fim de a demarcar das suas interpretações autárcicas e de a pôr a recato da influência negativa dos vários imperialismos epistemológicos, coisa bem distinta da aconselhável prática interdisciplinar.

A sua inserção na "espiral sem fim» destas relações desdramatiza a opção segundo a qual toda a ciência só poderá considerar-se definitivamente constituída quando tiver alcançado uma irredutível autonomia de conceitos, de métodos e de objectos. Mas, as «recepções» conceptuais e metodológicas só serão legítimas quando não se abdica do que especifica um dado projecto científico. Na matéria em apreço, isso obriga a que a perspectiva histórica não seja negligenciada, dado que ainda tem valor programático a velha definição, há muito avançada por Marc Bloch, segundo a qual a história é "a ciência do homem no tempo".

Pensando-se deste modo, não tem muito sentido andar-se, debalde, à procura de um exclusivo método, embora se reconheça, como se assinalou, que, a nível técnico, os velhos preceitos de crítica documental, quando reactualizados, mantêm uma utilidade que a retrospectiva do historiador não pode pôr em causa, sob pena de começar a confundir a historiografia com a ficção. Num plano mais epistemológico, também se tem de relativizar a excessiva dicotomia entre compreensão e explicação, pois, se é o problema a definir o objecto e a «inventar» o documento, também deve ser ele, no próprio processo da sua comprovação, a condicionar o uso de métodos que possam tornar mais convincentes os seus resultados. Explicar por causas e/ou compreender intençôes são atitudes que decorrem do jaez das perguntas feitas às informaçôes retiradas da massa documental que o processo foi seleccionando. Como afirmou Paul Ricœur (1955), «la compréhension n'est donc pas l'opposé de l'explication, elle en est 
au plus le complément et la contrepartie». E, sem a obsessão do causalismo nomotético ou do dualismo à Dilthey, quem decide acerca do grau das suas correlaçôes é a problemática.

Não se ignora as propostas que foram avançadas por certos sectores da filosofia analítica, tendentes a demonstrar que o conhecimento histórico se aproxima das explicações nomotéticas, porque também opera com deduçôes causais (C. G. Hempel, 1979). Mas os distanciamentos críticos tomados no seu próprio interior (como os de Arthur C. Danto, 1989) não podem ser esquecidos, nem se deve menosprezar o debate acerca da intrínseca dimensão narrativa da historiografia, tanto mais que as lições vindas da corrente hermenêutica (Droysen, Windelband, Dilthey, Rickert, Simmel, Weber, Croce, Ortega y Gasset, Aron, Gadamer, etc.) solidificaram as prevençôes face aos monismos metodológicos e ao império das explicações quantitativas.

Na verdade, os anos 1950 e 1960 foram o período da euforia da redução do histórico ao reino da res extensa. A nova história económica provocou a reformulação dos conceitos de documento e da própria ideia de irreversibilidade e singularidade do facto histórico. E os ciclos económicos mostravam que podia ler-se o passado a partir de «repetições» e similitudes, enquanto o seu ordenamento em séries lhes dava um valor informativo indesmentível que se compaginava bem com o uso da quantificação. A revolução informática reforçou ainda mais a ideia de que a historiografia só seria uma ciência se conseguisse alcançar explicações de tradução mensurável. E já se viu nesse entusiasmo a presença de um novo "complexo galilaico», porque se teria descoberto que a sociedade, tal como a natureza, estava escrita em caracteres matemáticos.

Rejeitar, liminarmente, esta via, será cometer num erro parecido, ainda que de sinal contrário. A riqueza patentiada pelo renovamento historiográfico revela que não existe explicação sem compreensão, embora a combinatória entre a exterioridade e a interioridade intencional, que a compreensão exige, esteja dependente da natureza do questionário, premissa que determina o objecto a investigar, o corpo documental mais adequado para a indagação do verdadeiro e, por conseguinte, os métodos mais ajustados ao sucesso desse desiderato. Ora, se existem temas que consentem uma relação de maior «exterioridade» entre o sujeito cognoscente e o objecto, isto é, que permitem ex-plicar, outros só poderão gerar conhecimento se aquele prender o sentido que, consciente ou inconscientemente, tem nos vestígios uma materialização sígnica cuja semântica, porém, só se desvelará desde que interrogada em termos qualitativos.

A hermenêutica introduz-nos no âmago da alternativa compreensivista e na busca do sentido das acçôes humanas, explícita ou implicitamente insinuado em todos os documentos históricos. E pressupor o círculo hermenêutico (relação parte todo) e a empatia (Erlebnis) constitui uma atitude metodológica fundamental, o que concita à prática de raciocínios analógicos, pois as intenções que terão presidido às acções passadas só serão compreendidas se forem vividas na interioridade do historiador. Sem esta abertura não existe, de facto, com-preensão. Para que não se peque por anacronismo, a precariedade que advém desta condicionalidade não pode ser negligenciada: a compreensão do outro ausente, que possibilita a chegada do passado ao presente, só pode ser feita através de mediaçóes semióticas. Mas, se basta a audição de um grito, por exemplo, para se despertar a analogia com a dor, ela não pode ser confundida com a experiência da própria dor, tanto mais que muitos sinais sugerem ser o que não são. 
Mesmo nas relações entre indivíduos vivos, um eu só entraria na compreensão plena de um outro se deixasse de ser ele mesmo, passando a ser o outro que nele se compreende; o que constitui, por dissolução e não distanciamento, uma impossibilidade ontológica e epistémica. Por outro lado, a busca exclusiva da intencionalidade deixa sem resposta os chamados "efeitos perversos» e inconscientes da acção e tende a transformar toda a história em história das ideias, exagero praticado, entre outros, por Collingwood.

Seja como for, aceitar-se que são os problemas que definem os métodos possibilita uma atitude aberta perante todas estas questôes, sem que isso signifique, contudo, a apologia de qualquer eclectismo, ou a busca de sínteses artificiais. A experiência mostra existirem interpretaçôes históricas que extraem dos documentos a máxima explicabilidade através do uso de métodos quantitativos ou da utilização de «leis» de outras ciências. Mas, por outro lado, a pluralidade e a renovação da historiografia actual também indica que outras só serão comprovadas com o recurso a análises qualitativas, enquanto outras, ainda, aconselham a fazer-se combinatórias metodológicas. Em resumo: os debates epistemológicos contemporâneos invalidam uma concepção unicitária de ciência, pondo em causa o dualismo clássico entre ciências da natureza e ciências do espírito e, até, entre racionalidade e irracionalidade (Prigogine e Lakatos). Dir-se-ia que se chegou a um tempo da superação dos "complexos de inferioridade» e do divórcio entre as chamadas "ciências duras» e "ciências moles».

A hora será de intercâmbio e de colaboração, pois se, no século XIX, os conhecimentos sobre o homem se "travestiam» com a roupagem das ciências da natureza — criando problemas desfocados e irrespondíveis —, actualmente o diálogo é diferente: a realidade humana e social necessita das explicações sobre a realidade física e biológica; mas estas também incorporam modelos e conceitos das ciências humanas e estão imbuídas da ideia de que não existe um vazio entre valores e conhecimento, porque, como Edgar Morin (1982) tem defendido, todo o saber, para estar ao serviço do homem, tem de produzir uma ciência com consciência.

Neste quadro, será justo defender que a historiografia é uma ciência do homem, ou, talvez melhor, uma sagesse que compreende explicando o passado, pois comparticipa numa circularidade epistemológica posta em movimento dialéctico pelo facto de todas as ciências serem, em última análise, ciências do homem e de os seus relacionamentos dependerem mais da natureza dos problemas que postulam, do que das afinidades ônticas da realidade que referenciam. Concorda-se, assim, com os esforços feitos para se superar a disjunção histórica entre "natureza» e "cultura». A ciência actual tem de jogar com categorias como as de caos e complexidade e com a ideia de que representa, tão-só, uma leitura parcial e provisória de uma realidade incerta e com fronteiras imprecisas ou móveis. Por conseguinte, se, não há muito, se acreditava que a sua missão quase sagrada consistia em eliminar a indeterminação e a imprecisão, hoje já não se duvida que a diversificação das ciências e dos seus efeitos - tidos, por alguns, como perversos - foram descredibilizando este convencimento. Dir-se-ia que, mesmo nas chamadas "ciências duras», se assiste ao "regresso" do seu matricial cariz hipotético-dedutivo, humildade que se tem traduzido na maior relevância dada ao "princípio da incerteza» e ao inevitável papel da correlação entre o sujeito e o objecto na génese de todos os campos científicos. 


\section{O historiador como sujeito pré-ocupado}

Em historiografia, a narração explicativa/compreensiva de uma problemática significa o ordenamento dos factos — retirados dos documentos (heurística e hermeneuticamente tratados) — numa estrutura que organiza temporalmente o cumprimento de uma estratégia gizada para produzir efeitos cognitivos. Modo de dizer que, na linha dos alertas lançados pelo pensamento hermenêutico alemão e pela filosofia crítica de inspiração kantiana, se está em face de uma valorização do papel do sujeito-historiador. Daí que o projecto dos Annales, sintetizado no programa da "história-problema», só seja novidade dentro de uma cultura onde imperava um exagerado cientismo, e por ter sido formulado, não de fora, mas de dentro da própria prática historiográfica. No entanto, este pano de fundo comum leva a que se pergunte: quais são as características do sujeito-mediador que fazem com que, agora de uma maneira mais assumida, o conhecimento do passado seja, também, um conhecimento feito a partir do presente-futuro?

Sabe-se que a interpretação estreita do paradigma da ciência da natureza pressupunha a existência de uma ruptura ôntica e epistémica entre o sujeito e o objecto, condição tida por necessária para se alcançar leis universais e, portanto, despidas de qualquer projecção subjectivista. Como se viu, a versão historiográfica deste apriorismo ganhou um curso relativo nas correntes que acreditavam ser possível, com a utilização da metodologia adequada, reconstituir-se o passado "tal qual ele aconteceu». Recorde-se que a lição anti-cartesiana de Vico já tinha sugerido um posicionamento diferente: o passado pode ser conhecido, precisamente porque os seus vestígios são «sinais» de acções do homem.

Em certo sentido, o mesmo se afirmava no idealismo objectivo alemão — ao pressupor-se que todo o racional é real — e, embora num outro registo, em Jules Michelet, quando, no seu célebre prefácio à Histoire de France (1869), não recalcou a "presença» do historiador, com as suas paixões e as suas emoções, na sua obra: somente uma relação amorosa com o objecto permitiria apreender o passado com verdade (G. Bourdé e H. Martin, 1983). E as correntes hermenêuticas procuraram fundamentar essa inevitável relação dialógica que existe entre o presente-futuro e o presente-passado. Por sua vez, ainda que com outros argumentos, as novas historiografias do século XX, ao destacarem a importância da hipótese ou dos problemas na produção do conhecimento, deram uma análoga valorização ao cariz mediado e, até certo ponto, "presentista» da historiografia.

Para se caracterizar tal mediação, bastará salientar, sem mais, o "papel activo do sujeito»? Afinal, de que sujeito se trata? O je cartesiano? O eu transcendental de Kant, como pretendia a filosofia crítica da história brilhantemente praticada, entre outros, por Raymond Aron $(1948,1965,1974,1984)$ ? Ou a palavra sujeito somente se refere à sujeição dos indivíduos a estruturas que os atravessam e ultrapassam?

Na perspectiva que tenta explicar historicamente as questôes historiográficas, esse sujeito só pode ser o historiador, pois a componente subjectiva é influenciada pela própria historicidade que o trespassa, bem como pelo lugar - o locus — de onde ele interroga os sinais do passado. E é neste contexto que se acha limitadas as posições das filosofias críticas que destemporalizam o sujeito, e se reconhece maior utilidade a propostas como a expressa no conceito de "operação historiográfica» que tanto seduziu 
Paul Ricœur, nomeadamente em La mémoire, l'histoire et l'oubli (2000), conjuntura em que, em carta, terá confessado a Bertrand Müller: "J'ai été heureux de me retrouver dans le voisinage de Michel de Certeau» (in F. Dosse, 2006).

É um facto que, ao não se recalcar a mediação presentista, o historiador emerge num mundo pré-ocupado (Merleau-Ponty) de memórias, ideias, valores, interesses sociais, em função do qual se pre-ocupa. Mas só o pode fazer no seio de uma pré-existente linguagem que transmuda a inquietação em problema. E como a res gestae, ontologicamente falando, é o não-ser (o reino dos mortos), o passado só será «reinventado" se o presente interpelar os seus vestígios, a fim de os descodificar. E, ao pôr em funcionamento o questionário, o historiador começa a romper com a memória e a condicionar, de uma maneira mais crítica e racional, a escolha do objecto a investigar.

Esta filtragem subjectiva não pode degenerar, porém, em subjectivismo. Daí, a necessidade que ele tem de adoptar uma atitude crítico-argumentativa em face dos discursos que pretendem chegar a conhecimentos objectivos. Sabe-se que H. I. Marrou o convidou a fazer a sua epochê, atitude metódica que, quando erradamente interpretada, parece defender que o sujeito cognoscente pode pôr a sua época entre parêntesis, essa ilusão maior das filosofias críticas da história. Convirá lembrar, todavia, que as práticas científicas ocorrem sempre num espaço e num tempo que não lhes são exteriores. Acolhendo o velho anátema de Nietzsche contra o historicismo, dir-se-ia que a história só será útil como história viva. E este conselho só será cumprido se o diálogo entre o presente e o passado não for mumificado pela erudição ou pelo antiquarismo, ou, o que é o mesmo, pela a historicização do sujeito epistémico que o anima.

Ora, para se compreender a historicidade que atravessa o trabalho historiográfico, relembre-se que todo o historiador trabalha a partir de um locus, situação que terá de ser equacionada, porque se projecta no interior do seu resultado. Com efeito, ele não é uma abstracção, mas alguém (ou um colectivo) imbuído de formação histórica e que, com a sua crescente "profissionalização" a partir do século XIX, problematiza e interpreta dentro de um "local» que, antes de tudo, age como instituição. E é esta instância que, em última análise, credibiliza e garante as bases de produção da linguagem científica, ao mesmo tempo que socializa, como uma espécie de lei, o cânone do grupo. Com estas chamadas de atenção, também se pretende afirmar que o topos impossibilita desligar-se a análise das representações historiográficas da sociologia da sua produção, porque, se aquele, por um lado, impulsiona e enforma o trabalho historiográfico, por outro lado, também age como instância censória, já que, se estimula certas pesquisas, secundariza e recalca outras.

Em síntese: o locus, enquanto instituição, tende a excluir do seu campo problematizador tudo o que respeita à explicitação da sua própria condição de instância sobredeterminadora da produção dos saberes (Michel de Certeau). Dir-se-ia que ele é o "não dito" da operação, porque, voluntária ou involuntariamente, a sua mediação escamoteia algo que - não obstante os votos mais puristas de Paul Veyne, Raymond Aron e mesmo de um Paul Ricœur até à publicação de La mémoire, l'histoire et l'oubli (2000) — lhe é intrínseco: o vínculo que existe entre os textos historiográficos e as sociedades concretas que os produzem.

Reconhecida a impossibilidade de a historiografia criar um saber imediato, fruto do ver, e reafirmado o seu cariz mediato e mediado, ter-se-á de contar com o activismo 
do sujeito-historiador no resultado final. Desde logo: no trabalho selectivo que está a montante da operação, mas que, como na recordação, ao dar representância a algo, muito deixa esquecido; na subida da fase arquivistica para o nível explicativo-compreensivo, ao pôr em acção escalas espaço-temporais e ordenamentos de causalidade que só ele pode projectar no caos das informações recolhidas; no plano da interpretação, já que este implica o distanciamento entre o sujeito e o outro (ausente), cabendo ao primeiro proceder a uma hermenêutica não anacrónica e, portanto, dita na linguagem de quem interroga o que está mudo, abrindo janelas à imaginação historiográfica; por fim, na busca da objectividade, porque esta é indissociável de uma inevitável relação inter-subjectiva.

Em suma: o trabalho dos historiadores tem a ver, directa ou indirectamente, com a vida dos homens no tempo. Daí, a especificidade da representância, que ele constrói entre a narrativa e a realidade referenciada, pressuposto ôntico que só através da mediação do questionamento pode «falar» como objecto epistémico (F. Dosse, 2006). Assim se convida a que não se confunda este último com a mecânica mimesis da res gestae, e a que se compreenda porque é que a imaginação historiográfica impulsiona uma poética que, não obstante todos os seus condicionantes, sobrepõe a interpretação à ilusão verista veiculada pela imagem.

\section{Um referente também ausente}

Como se viu, a mediação do sujeito-historiador está em toda a operação historiográfica e esta culmina numa narrativa que almeja suscitar, no leitor, efeitos cognitivos, para além dos de índole estética que também pode provocar. Pensando bem, toda ela é guiada por uma estratégia de convencimento que postula a existência de um prévio, mas permanente, contrato de veridicção entre o historiador e o receptor, premissa omnipresente em todos os níveis do processo e que acaba por ser o fio condutor da estrutura lógica da sua trama.

Facilmente se intui que não se trata só de imaginação e que basta a auto-análise do funcionamento da memória para se detectar, na recordação, uma referencialidade que, apesar de ausente, se sabe exterior ao evocador. E, quando do passado só existem vestígios (e não memórias vivas), também se pode fiar no testemunho, desde que este seja devidamente rectificado e credibilizado. Assim sendo, se a narrativa memorial, com a sua carga de verosimilhança, é prova de que se pode sair da zona dos puros enunciados para se referenciar o domínio do não discursivo, como não reconhecer análoga capacidade à historiografia?

Por outras palavras: se a historiografia é impossível sem a existência da imaginação - desencadeada por inquietaçôes insatisfeitas e requerida pelo seu cariz mediato, pela necessidade de se porem problemas aos vestígios, e pelo teor fragmentário dos «restos» deixado pelo passado — , será erro, porém, confundi-la com a imaginação estética. Esta não está selada por qualquer pacto cognitivo, nem tem que prestar contas da «realidade» que ficciona, mesmo quando recorre a «factos» tidos por históricos, porque o contrato do escritor-ficcionista com o seu leitor não é de índole cognitiva, mas de matiz estético. 
A imaginação historiográfica também não pode ser identificada com a que está subjacente ao recordar, não obstante a sua análoga convocação da ausência e uma comum reivindicação do verosímil. Como experiência vivida, a segunda tem dificuldade em se libertar do império da imagem, enquanto a primeira possui um cariz mais racional e controlado, e tenta convencer pela prova, sabendo, contudo, que não pode apelar a experimentos directos, nem defender que o narrado é a adequação do intelecto à "coisa" (adcequatio rei et intellectus). Isto é, tal como a recordação no seu âmbito próprio (e particularmente no culto dos mortos), também a historiografia é uma poética de ausência, pois re-presentifica o que já não existe. Fá-lo, contudo, num contexto em que a sua imaginação interpretativa (que cria as hipóteses e as interpretaçôes) não pode dispensar o suporte documental e uma ordem diegética de cariz mais demonstrativo.

A ultrapassagem da ideia empirista de verdade foi igualmente perfilhada por todas as concepçôes que defenderam ser possível conceptualizar e explicar o acontecido segundo regras que, mesmo sendo incapazes de demonstrar leis por via experimental, se aproximam do conhecimento nomotético. Porém, Roland Barthes (1967) reduziu os factos à linguagem, e algum pós-modernismo mais radical apostolou que já não existem dados e factos, mas tão-somente interpretaçôes, pelo que as clássicas divisões entre o verdadeiro e o falso, a verdade e a ficção teriam perdido o seu significado (Gianni Vattimo, 1987). Sem irem tão longe, outros, como Paul Veyne (1979), afirmaram que os homens não produzem nem o verdadeiro nem o falso, mas somente $o$ existente. Na expressão de Elena Sandoica (1995) - cuja síntese estamos a seguir —, nesta época de crise, a verdade estala, dispersa-se num movimento que a metamorfoseia numa espécie de verdade vagabunda.

A questão da veracidade terá que ser debatida, não só no quadro das relações entre o discurso histórico e a realidade que, embora «ausente», aquele referencia, mas também em função da sua capacidade de convencimento, a começar dos próprios historiadores. Chamando à colação o conceito kuhniano de paradigma, segundo o qual as realizaçôes científicas mais universalmente reconhecidas, durante um certo tempo, fornecem modelos à comunidade científica, poder-se-á esclarecer melhor o cariz não metafísico, não absoluto e, portanto, não fechado do saber histórico: uma dada interpretação (sobretudo se for controversa) terá uma base de convencimento tanto mais ampla quanto mais durável for o reconhecimento do seu maior poder explicativo/compreensivo, em confronto com outras sobre o mesmo objecto.

Não se pense, porém, que aquele leitor-receptor está exclusivamente no exterior da própria escrita. A sua omnipresença data do início da operação, seja como "autoridade» positiva, seja como horizonte de polémica e de contestação, seja como leitor interiorizado como juiz. Sendo assim, no que se escreve e no como se escreve perpassa e ecoa, como um ausente-presente, o "olhar» vigilante daquele para quem se escreve, nem que seja, antes de tudo, para o próprio sujeito-historiador quando ele se desdobra em crítico de si mesmo.

Feita a distinção entre o objecto (conceito epistemológico, criado pelo sujeito) e a realidade (conceito ontológico), a historiografia poderá construir um saber objectivo, pois a intuição analógica (desde logo, com a nossa própria recordação) dá credibilidade à suposição de que existiu uma realidade que, através da certificação, testificação 
e interpretação dos seus vestígios, pode ser representificada como um produto não exclusivo da imaginação subjectiva. E esta experiência vivida, desde que escorada em normas consensuais acerca das técnicas de investigação e no contrato cognitivo que põe em movimento a operação, faz com que a imaginação historiográfica não possa ser confundida com a ficção, mesmo que se reconheça que a veracidade que procura alcançar só existe no próprio discurso historiográfico, ou, segundo outros, na correlação dialéctica entre o discurso e a sua recepção.

Foi precisamente para cortar com as ilusões vindas, quer da crença no mimetismo imediato da representação, quer, no pólo oposto, da redução desta à pura ficcionalidade, que Paul Ricœur preferiu falar, já em Temps et récit e, depois, em La Mémoire, l'histoire et l'oubli, em representância. Com este conceito, procurou enfatizar o cariz do pacto inerente à investigação histórica, à luz do qual «l'historien se donne pour objet des personnages, des situations ayant existé avant qu'il n'en soit fit récit». E visou distingui-lo do conceito de representação, porque este é incapaz de denotar o que Ricœur qualificou como «lieutenance du texte historique». Ouçamo-lo em Temps et récit: «daremos o nome de representância (ou de lugar-tenência) à relação entre as construções da história e os seus vis-à-vis, a saber, um passado ao mesmo tempo abolido e preservado nos seus rastros». O que também possibilita dialogar-se dialecticamente com os contributos dos que, depois do linguistic turn, haviam justamente apontado para a inevitável índole narrativa da escrita da história, mas para se distanciarem das suas teses extremas. Para isso, "contre l'indistinction épistémologique entre fiction et histoire», ele defendia «l'exigence véritative du discours historique» (François Dosse, 2006). Com propósito idêntico, mas com o intuito de explorar as analogias que surpreendemos entre a historiografia e a memória, aqui se usa a palavra re-presentificação (por sua vez, Collingwood [s.d.] utilizou o conceito de re-presentação). Modos de expressar os esforços cognitivos do homem para se situar na ordem do tempo.

\section{A história como escrita; a escrita como história}

Não restam dúvidas: todo o trabalho historiográfico finda num «texto», o que levou a transformar-se num lugar-comum caracterizá-lo como uma escrita: a escrita da história. Todavia, quem o faz só raramente destaca a outra face que o qualificativo encobre: a escrita não é um instrumento neutro, pois também é um produto histórico, como exemplarmente tem demonstrado, nas últimas décadas, a Begriffsgeschichte desenvolvida pela escola de Reinhart Koselleck e seus seguidores (Antonio Gómez Ramos, 2004). Salientar este aspecto será outra maneira de clarificar um pouco melhor algo que comummente surge confundido: afinal de contas, a vida de cada individuo não se esgota na sua narração e a narração também faz parte da vida.

Por outro lado, como a historiografia estuda o passado que já foi vida, a sua linguagem, por mais que tenha (e deva) recorrer a conceitos (Paul Veyne, 1979), não pode ser uma metalinguagem, porque dificilmente poderá dizer o que reconstrói, a partir do presente-futuro, sem recorrer a símiles, metáforas, alegorias, etc. Ela nunca poderá ser, em suma, uma nomenclatura, e desde a psicanálise se sabe que um indivíduo, ao falar, também é falado, e as palavras e os conceitos são igualmente criações 
históricas, cujo uso carreia conotações nem sempre racionalmente controláveis. Daqui deriva o grande e incontornável paradoxo da escrita da história: se ela pretende narrar o "tal como» aconteceu, só o poderá fazer na linguagem do tempo de quem interroga os restos sígnicos do que passou.

Estas considerações obrigam a que se chame a terreiro alguns dos temas mais debatidos nas últimas décadas, em boa parte devido à saturação e à descredibilização dos modelos cientistas. O que, como se viu, gerou movimentos de ruptura ou de revisão, que têm sido colocados sob o lema do "regresso»: "regresso» da narrativa, "regresso» do sujeito, «regresso» do acontecimento, «regresso» do político, «regresso» da própria historiografia ao seu antigo estatuto de um saber que, afinal, estará mais próximo da literatura do que dos paradigmas de qualquer ciência. E, como é sobejamente conhecido, esta última questão deu azo a escritos decisivos de Paul Veyne, Roland Barthes, Paul Ricœur, Hayden White. Pelo que, hoje, os historiadores já não podem pensar que a sua escrita é um mero veículo extrínseco à verdade descritiva: como em todos os domínios, o pensamento sobre o passado é uma linguagem e historiar é «contar uma história», é construir uma ordem narrativa em que a forma também é conteúdo.

Isto não significa que não se deva estar atento à confusão dos campos, como acontece com as interpretaçôes mais formalistas e estruturais ( $\mathrm{H}$. White) que tendem a esquecer-se que são um produto histórico da conjuntura em que o estruturalismo foi hegemónico no domínio das ciências humanas, bem como do facto de o historiador construir textos que não se esgotam na sua coerência interna, ou num arquetípico-estrutural de reprodução de tropos que, afinal, parece somente estar adequado aos exempla eleitos para se ilustrar a sua verdade: as ideias históricas e a historiografia do século XIX europeu e, particularmente, a francesa. Porém, aceita-se a trama como mediação entre os acontecimentos e certas experiências humanas da temporalidade, ordenando-as num conjunto inteligível que lhes incute sentido. Mas também se considera improfícua a adesão acrítica a algumas teses narrativistas, particularmente: às que não reconhecem autonomia (não escrevemos independência) às especificidades dos temários historiográficos; às que apontam para a existência de uma analogia demasiadamente estrita entre a narração histórica e a narração ficcionada; e às que desvalorizam o que a historiografia não pode alienar: a sua escrita é sempre a forma de um "conteúdo de verdade», cujo estatuto só pode ser julgado pela capacidade de convencimento de uma diegese comandada por uma finalidade veritativa.

Como esta não é dominantemente estética, ter-se-á de perceber que os seus propósitos de objectividade criam, em relação à ficção, problemas acrescentados: o da veridicidade e o da referencialidade (Julio Aróstegui, 1995), exigências que não poderão ser menorizadas, sob pena de ela, depois de se ter emancipado do império cientista, se deixar diluir no campo da literatura, perdendo, assim, a possibilidade de reforçar a sua vocação medianeira dentro da constelação plural de todos os saberes. Se o fizer, estará a demitir-se das suas pretensões cognitivas, e a esquecer-se da função anamnética e, de certo modo, justiceira, que também a fez nascer. No entanto, uma mentira acreditada como verdade só será desconstruída como mentira à luz dos critérios que possibilitam demonstrar a sua falsidade. Questão importante, mas de somenos para todos aqueles que reduzem a história à auto-suficiência da sua representação escrita. 


\section{Um conhecimento sem fim da história}

Este longo excurso sobre a historiografia enquanto saber mediato e mediado teve por finalidade última fazer ressaltar as características, não do progresso histórico, mas do progresso dos conhecimentos históricos nos vários níveis que o foram materializando, em função dos «regimes de historicidade» que eles pressupunham. E a reflexão mais epistémica, combinada com os ensinamentos extraídos da história da historiografia, indica que se acreditou no seu perfil acumulativo sobretudo quando foi dominante a concepção evolutiva da diacronia social, alicerçada na crença na capacidade perfectível do homem. Optimismo que configurou o progresso historiográfico (ilustração do progresso que ocorria ao nível da res gestae) como um «edifício» em crescimento, ao qual, desde os seus caboucos, cada geração iria sucessivamente levantando mais andares até se chegar a um telhado que iria ser posto, algum dia, logo que se esgotassem os documentos. Esse seria o momento em que, depois de séculos de análise, se faria a síntese definitiva da história universal.

Pode sustentar-se que, descontadas as especificidades das várias correntes, essa expectativa dominou a historiografia oitocentista. Recorde-se que, entre outros, a imagem do «edifício» foi igualmente a preferida por Alexandre Herculano, numa espécie de proto-positivismo que a "escola metódica» francesa, inspirada na lição alemã de Niebuhr e Ranke, explicitará nos finais de Oitocentos. Não deve surpreender este casamento, já que a visão acumulativa, decorrente do evolucionismo histórico, se compaginava bem com uma ideia de tempo pautada pela sua irreversibilidade cronológica e progressiva. Mas, conquanto se acenasse com a promessa de um progresso na história (res gestae), a busca desse ideal sintético, ainda que de concretização longínqua, não implicaria reconhecer-se um fim da história do conhecimento histórico?

Não se nega que, no primeiro nível da operação historiográfica, da fiabilidade dos documentos e do apuramento sólido dos factos e respectiva ordenação cronológica se extraem informaçôes muito consensuais. Porém, não se pode esquecer que a explicação/compreensão e a escrita introduzem patamares de mediação e de relações de alteridade que não consentem que a metáfora do edifício em construção ilustre, adequadamente, o caminhar da historiografia, pois, quanto mais se ousa na interpretação, mais aumentam as possibilidades de controvérsia.

Em termos muito genéricos, diz-se, amiúde, que toda a historiografia é história contemporânea (Croce), não por ter como objecto o «tempo presente», mas devido à circunstância de ser o "presente» o foco das retrospectivas, incluindo aquele que ainda não há muito era só futuro. Característica que se acentuou com o presentismo contemporâneo. No entanto, reconhece-se que, hoje, também se pluralizaram e se tornaram mais complexas as visões do mundo. Logo, como estranhar que esse horizonte se projecte na hermenêutica histórica? Só o negará quem se julgar instalado num eterno e monolítico tempo real.

Por outro lado, actualmente, também se diz que se vive num «tempo de incertezas». E só os mais dogmáticos terão dificuldades em não aceitar tal diagnóstico. Ora, este parece desconstruir a auto-suficiência da visão punctiforme do tempo, tanto no plano da res gestae, como no da historia rerum gestarum. Vendo bem as coisas, aquela sensação decorre do que se julgava vir a acontecer, ou melhor, das previsóes do passado quando 
ele foi presente, porque ela não pode existir em relação ao que ainda não é, horizonte que constitui somente um mundo de possibilidades. E, como o não certo é o seu modo de ser, a incerteza não deriva do futuro em si, mas dos fracassos do presente, incluindo o da sua definitiva permanência.

No campo aqui em causa, tem-se por certo que a historiografia é renovada, sobretudo, pela aptidão para se perguntar (e provar) o novo. É que, mais do que somar andares a um prédio há muito planificado e em construção, a mediação do sujeito-historiador remodela-o e, principalmente, ergue novas construçóes cujo perfil arquitectónico não deve ser traçado como se de uma sucessão de casas em banda se tratasse. Dito de outro modo: já não se pode regressar ao sonho do saber definitivo, pois o conhecimento não pode esgotar os enigmas do mundo. A própria incerteza instala a insatisfação e a curiosidade, e as condicionalidades apontadas vedam-lhe o escopo universalista, pois minam a fé no próprio conceito evolucionista do progresso das ciências e, particularmente, das ciências históricas. E solucionar problemas não é fechar o mundo, mas acrescentar novos mundos aos mundos conhecidos.

Com efeito, a história da historiografia tem mostrado que esta não progride somente por acumulação, mas também por reformulação, deslocamentos e irrupção de novas problemáticas. Explica-se: a joeira do sujeito, com todas as suas pré-ocupaçóes (epistemológicas, culturais, sociais, psicanalíticas, linguísticas), faz com que a historiografia seja um trabalho sempre em aberto, tanto mais que a sua capacidade de dar translucidez ao passado a partir de traços — que, se revelam, também escondem -, nunca conseguirá captar aquilo que, no outro e no diferente, sempre escapará à perscrutação do presente-futuro. Nas palavras do velho Herculano, escritas meio século antes dos fundadores dos Annales, «a História pode comparar-se a uma coluna polígona de mármore. Quem quiser examiná-la deve andar ao redor dela, contemplá-la em todas as suas faces». A frase é sábia, mas esquece-se desta outra perspectiva: os textos que lhe dão visibilidade também são, com as suas re-presentificaçôes cognitivas, escultores desse mármore, ao darem voz aos apelos que, vindos do passado, solicitam futuros que só o presente, ou melhor, o cruzamento entre memória e expectativa poderá esculpir. Deste modo, não será descabido defender que a representância historiográfica é uma poética da ausência, pois, no muito que dá a conhecer, sempre existirão passos do homem que ficarão no esquecimento (ir)reversível.

\section{BIBLIOGRAFIA}

AA.VV., Fernand Braudel e a história. Chateauvallon, Jornadas Fernand Braudel, 18, 19 e 20 de Outubro de 1985, Lisboa, Teorema, 1987.

AA. VV., Debates por una historia viva, Bilbao, Universidad de Deusto, 1990.

ANDrÉs-Gallego, José, New history, Nouvelle histoire, Madrid, Actas, 1993.

ANKERSMIT, Frank, Narrative logic. A semantic analysis of the historian's language, Haia-Boston-Londres, M. Nijhoff, 1983.

Ankersmit, Frank R. e Kellner, Hans (org.), A New philosophy of history, Londres, Reaktion Books, 1995.

ANKersmit, F. R., "Historiography and postmodernism», History and Theory, XXVIII, n. ${ }^{\circ} 2,1989$. 
Ankersmit, F. R., «Reply to Professor Zagorin», History and Theory, XXIX, n. 3, 1990.

ApplebY, Joyce, HunT, Lynn e JACOB, Margaret, Telling the truth about history, New York-London, W. W. Norton \& Company, 1995.

ARON, Raymond, Introduction à la philosophie de l'histoire. Essai sur les limites de l'objectivité historique, Paris, Gallimard, 1948.

ARON, Raymond, Philosophie de l'histoire. Essai sur une théorie allemande de l'histoire, Paris, J. Vrin, 1965.

ARON, Raymond, "Comment l'historien écrit l'epistémologie: a propos du livre de Paul Veyne», Annales E.S.C., XXLX ano, n. ${ }^{\circ}$ 6, 1971.

ARON, Raymond et al., L'historien entre l'ethnologue et le futurologue, Paris, Mouton, 1972.

Aron, Raymond, La Philosophie critique de l'histoire, Paris, Gallimard, 1984.

ARÓstegui, Julio. La investigación histórica: teoría y método, Barcelona, Crítica, 1995.

AtKinson, R. F., Knowledge and explanation in history, Ithaca, Cornell University Press, 1978.

Atsma, Hartmut e BurguiÈre, André (dir.), Marc Bloch aujourd'hui. Histoire comparée et sciences sociales, Paris, Éditions de l'École des Hautes Études, 1990.

Aymard, Maurice, "Histoire et comparaison», in Atsma, Hartmut e BurguiÈre, André (org.), Marc Bloch aujourd'hui. Histoire comparée et sciences sociales, Paris, Éd. de l'École des Hautes Études, 1990.

BACHELARD, Gaston, O Novo espirito cientifico, Lisboa, Ediçōes 70, s.d.

BANN, Stephen, "Art history in perspective», in The Inventions of history. Essays of the past. Manchester/ Nova Iorque, Manchester University Press, 1990.

BARTHES, Roland, «Le discours de l'histoire», Social Science Information, Paris, Unesco, VI, 4, 1967.

Bermejo, J. C., Replanteamiento de la historia. Ensayos de historia teórica, t. II, Madrid, Akal, 1989.

Bermejo, J. C., Fundamentación lógica de la historia, Madrid, Akal, 1991.

BERMEJO, J.C., «La historia, entre la razon y la retorica», Hispania, vol. 50 (174), 1990.

BERR, Henri, Histoire traditionnelle et la synthèse historique, Paris, Félix Alcan, 1935.

Berthelot, M., Les Origines de l'alchimie, Paris, Steinheid, 1885.

Bloch, Marc e Febvre, Lucien, Correspondance I La naissance des Annales. 1928-1993, Paris, Fayard, 1986.

BlOCH, Marc, Apologie pour l'histoire ou métier d'historien, Paris, Armand Colin, 1960.

Bourdé, Guy e Martin, Hervé, Les Écoles historiques, Paris, Seuil, 1983.

Bourdeau, Louis, Histoire et les historiens. Essai critique sur l'histoire considérée comme science positive, Paris, Félix Alcan, 1888.

Bourdieu, Pierre, Ce que parler veut dire. L'économie des échanges linguistiques, Paris, Fayard, 1982.

Boutier, Jean et Julia, Dominique, Passés recomposés. Champs et chantiers de l'histoire, Paris, Autrement, 1995.

BOYER, Alain, L'Explication en histoire, Lille, PUL, 1992.

BRAUDEL, Fernand, Écrits sur l'histoire, Paris, Flammarion, 1969.

Burguière, André (dir.), Dictionnaire des sciences historiques, Paris, PUF, 1988.

Burke, Peter, New Perspectives on historical writing, Cambridge, Polity Press, 1991.

BURKE, Peter, Formas de hacer historia, Madrid, Alianza, 1993.

BurKe, Peter, La Revolución historiográfica francesa. La escuela de los Annales: 1929-1989, Barcelona, Gedisa Editorial, 1996.

CARR, D., Time, narrative and history, Bloomington Indiana University Press, 1968.

CARr, E. H., Que é a história, Lisboa, Gradiva, s.d. 
Carrard, Philippe, Poetics of the new history. French historical discourse from Braudel to Chartier, Baltimore and London, The Johns Hopkins University Press, 1992.

CATroga, Fernando, "Alexandre Herculano e a historiografia romântica», TORGAL, Luís Reis et al., História da história em Portugal. Séculos XIX-XX, Lisboa, Círculo de Leitores, 1996.

Catroga, Fernando, Teoria da história e do conhecimento histórico, Coimbra, Faculdade de Letras, 1996 (edição policopiada).

Certeau, Michel de, L'Absent de l'histoire, Paris, Mame, 1973.

CERTEAU, Michel de, L'Écriture de l'histoire, Paris, Gallimard, 1975.

CHARTIER, Roger, A História cultural. Entre práticas e representaçôes, Lisboa, Difel, 1988.

Chartier, Roger, Au Bord de la falaise. L'histoire entre certitudes et inquiétude, Paris, Albin Michel, 1998.

Chesneau, J. Hacemos tabla rasa del pasado?, Madrid, Siglo XXI, 1977.

Collingwood, Robin G., A Ideia de história, Lisboa, Presença, s.d.

Collingwood, Robin G., The Historical imagination. An inaugural lecture delivered before the University of Oxford on 28 October 1935, Oxford, Clarendon Press, 1935.

CORnblit, Oscar, «Las concepciones de Hempel y Von Wright de la explicación en historia», in Reyes Mate et al., Filosofía de la historia, Madrid, Editorial Trotta, 1993.

Couteau-Bégarie, Hervé, Le Phénomène nouvelle histoire. Stratégies et idéologies des nouveaux historiens, Paris, Fayard, Economica, 1983.

CruZ, Manuel, "Narrativismo», in Reyes Mate et al., Filosofía de la historia, Madrid, Editorial Trotta, 1993.

Danto, Arthur C., Analytical philosophy of history, Cambridge Mass., Cambridge University Press, 1968.

DANTO, Arthur C., Historia y narración. Ensayos de filosofía analitica de la historia, Barcelona, Paidós, 1989.

DANTO, Arthur C., "The decline and fall of the analytical philosophy of history", in ANKERSMIT, Frank e Kellner, Hans (org.), A New philosophy of history, Londres, Reaktion Books, 1995.

Darnton, Robert, "Historia de la lectura», in BURKe, Peter (org.), Formas de hacer Historia, Madrid, Alianza Editorial, 1993.

DARNTON, Robert, «Diffusion vs. discourse: conceptual shifts in intellectual history and the historiography of the French Revolution", in BArros, Carlos (org.), Historia a Debate (Actas del Congreso "A Historia a debate", celebrado el 7-11 de Julio de 1993 en Santiago de Compostela), tomo II, Santiago de Compostela, Historia a Debate, 1995.

DelacroiX, Christian; Dosse, François; GarCIA, Patrick, Les Courrents historiques en France, $X I X^{e}-X X^{e}$ siècles, Paris, Armand Colin, 1999.

DelacroiX, Christian, «De quelques usages historiens de P. Ricoeur», Bertrand Müller (org.), L'Histoire entre mémoire et épistémologie, Lausanne, Édition Payot Larrousse, 2005.

Devulder, C., L'Histoire dans l'Allemagne. XIX siècle, Paris, Méridiens Klinsieck, 1993.

DiEHL, Astor Antônio, Cultura historiográfica. Memória, identidade e representação, Bauru, EDUSC, 2002.

DiltheY, Wilhelm, Introducción a las ciencias del espiritu, Madrid, Revista de Ocidente, 1966.

Dilthey, Wilhelm, Critica de la razón histórica, Barcelona, Peninsula, 1988.

DomansKa, Ewa, "An interview with Hayden White», Storia della Storiografia, n. ${ }^{\circ} 24,1993$.

Dosse, François, L'Empire du sens. L’humanisation des sciences humaines, Paris, La Découvert, 1995.

Dosse, François, L'Histoire en «miettes», des Annales à la nouvelle histoire, Paris, La Découverte, 1995 a.

Dosse, François, L'Histoire, Paris, Armand Colin, 2000.

Dosse, François, Paul Ricoeur, les sens d’une vie, Paris, La Découvert, 2001. 
DOSSE, François, «Paul Ricoeur, Michel de Certeau et l'histoire», Bertand Müller (dir.), L'Histoire entre mémoire et épistémologie. Autour de Paul Ricoeur, Lausanne, Payot, 2005.

Dosse, François, Pour Ricoeur et Michel de Certeau, L'histoire entre le dire et le faire, Paris, L'Herne, 2006.

DossE, François, «L'histoire à l'épreuve de la guerre des mémoires», Cités, n.o 33, 2008.

DRAY, W. R., Leggi e spiegazioni storiche, Milão, Il Saggiatore, 1974.

Droysen, J. G., Historica: Lecciones sobre la Enciclopedia y metodología de la historia, Barcelona, Alfa, 1983.

DuBY, Georges/Lardreau, Guy, Diálogos sobre a nova história, Lisboa, Publicaçôes D. Quixote, 1989.

DubY, Georges, L'Histoire continue, Paris, Odile Jacob, 1991.

Dulong, Renaud, Le Témoin oculaire. Les conditions sociales de l'attestation personnelle, Paris, Éd. de l'EHESS, 1998.

DuNK, Hermann Von Der, «Narrativity and the reality of the past. Some reflections», Storia della Storiografia, n. ${ }^{\circ} 24,1993$.

ECO, Umberto, «Prólogo», LoZANo, Jorge, El Discurso histórico, Madrid, Alianza, 1994.

ELKNA, Y. (ed.), The Interaction between science and philosophy, Nova Iorque, Humanitris Press, Atlantic Highlands, 1974.

ELIAS, Norbert, Compromiso y distanciamiento, Barcelona, Ediciones Península, 1990.

ELTON, G., Return to the essentials. Some reflections on the present state of historical study, Cambridge, Cambrigge University Press, 1991.

Engel, Pascal, «La philosophie peut-elle échapper à l'histoire?», in BouTier, Jean e JULIA, Dominique (dir.), Passés recomposés. Champs et chantiers de l'Histoire, Paris, Autrement, 1995.

Febvre, Lucien, Combats pour l'histoire, Paris, Armand Colin, 1953.

FERro, Marc, L'Histoire sous surveillance, Paris, Calmann-Lévy, 1985.

FInLey, Moses I., Mythe, mémoire, histoires. Les usages du passé, Paris, Flammarion, 1981.

FONTANA, Josep, La Historia después del fin de la historia, Barcelona, Crítica, 1992.

FONTANA, Josep, La Historia de los hombres, Barcelona, Crítica, 2001.

FOSTERS, Robert, «Achievements of the Annales school», in The Journal of Economic History, vol. XXXIX, n. ${ }^{\circ} 1,1979$.

FURET, François, $O$ Oficio da história, Lisboa, Gradiva, s.d.

GADAMER, Hans-Georg, "Herder et ses théories de l'histoire (regards sur l'histoire)», Cahiers de l'Institut Allemand, n. ${ }^{\circ}$ 2, Paris, Sorlot, 1941.

Gadamer, Hans-Georg, Le Problème de la conscience historique, Louvain-Paris, PUL-EBN, 1963.

GadAmer, Hans-Georg et al., História e historicidade, Lisboa, Gradiva, 1988.

GADAMER, Hans-Georg, Verdad y método, Salamanca, Ediciones Ségueme, 1988a.

GAdoffre, Gilbert, Certitudes et incertitudes de l'histoire, Paris, PUF, 1987.

Giard, Luce (ed.), Michel de Certeau. Cahiers pour le temps, Paris, Centre Georges Pampidou, 1987.

Giard, Luce; Martin, Hervé; Revel, Jacques, Histoire mysthique et politique. Michel de Certeau, Grenoble, Jérôme Millon, 1991.

Gilbert, Felix, History: politics or culture? Reflections on Ranke and Burckhardt, Princeton, Princeton University Press, 1990.

GinzburG, Carlo, Mythes, emblèmes, traces, Paris, Flammarion, 1989.

GinzBurG, Carlo et al., A Micro-história e outros ensaios, Lisboa, Difel, 1991.

GinZBURG, Carlo Il Giudice e lo storico, Turim, Einaudi, 1991ª. 
Gómez Ramos, Antonio, "Koselleck y la Begriffsgechichte. Cuando el lenguaje se corta con la historia»,

K. Koselleck, historia/Historia, Madrid, Trotta, 2004.

GOOCH, George P., Historia y historiadores en el siglo XIX, México, FCE, 1977.

Hartog, François, Le XIX'e, siècle et l'histoire. Le cas de Fustel de Coulanges, Paris, Gallimard, 1988.

Hartog, François, «Temps et histoire. Comment écrire l'histoire de France», Annales, n. ${ }^{\circ}$ 5, 1995.

HaRTOG, François, Le Miroir d'Hérodote. Essai sur la représentation de l'autre, Paris, Gallimard, 2001.

HarToG, François, Régimes d'historicité, présentisme et expériences du temps, Paris, Seuil, 2003.

Hartog, François, Évidence de l'histoire. Ce que voient les historiens, Paris, Éditions de L'École des Hautes Études en Sciences Sociales, 2005.

HARTOG, François, "Tempos do mundo, história, escrita da história», SAlGADO, Luiz Manoel Guimarães, Estudos sobre a escrita da história, Rio de Janeiro, 7Letras, 2006.

HarveY, J. Kaye, Los Historiadores marxistas britanicos, Saragoça, Universidad de Zaragoza, 1989.

Heller, A., Teoria de la historia, 5a ed., Barcelona, Fontamara, 1985.

Heller, A., Historia y futuro, Barcelona, Península, 1991.

Hempel, C. G., "The function of general laws in history», in H. Feigl e W. Sellars, Reading in philosophical analysis, New York, Knopf, 1949.

Hempel, C. G., La Explicación cientifica, Buenos Aires, Paidos, 1979.

Herculano, Alexandre, Opúsculos, vol. 5, Lisboa, Presença, 1986.

Hernández SAndoica, Elena, Los Caminos de la historia. Cuestiones de historiografía y método, Madrid, Ed. Síntesis, 1995.

HernándeZ SANDOICA, Tendencias historiográficas actuales. Escribir historia hoy, Madrid, Akal, 2004.

Heródoto, Histórias, Liv. 1. ${ }^{\circ}$, Lisboa, Edições 70, 1994 (introdução geral de Maria Helena da Rocha Pereira; introdução ao Liv. 1. ${ }^{\circ}$, versão do grego e notas de José Ribeiro Ferreira e Maria de Fátima Silva).

HESPANHA, António Manuel, «História e sistema: interrogações à historiografia pós-moderna», Ler Historia, 9, 1988.

Hespanha, António Manuel., "A emergência da história», Penélope. Fazer e desfazer a história, n. ${ }^{\circ}$ 5, 1991.

Himmelfarb, G., The New History and the old, Cambridge-Mass., The Belknap Press of Harvard University Press, 1987.

Hunt, Lynn et al., A Nova história cultural, São Paulo, Martins Fontes, 1992.

KaYe, H. J., The Powers of the past. Reflections on the crisis and the promise of history, Minneapolis, University of Minnesota Press, 1991.

Kellner, Hans, "Twenty years after: a note on 'Metahistories and their horizons», Storia della storiograffia, n. ${ }^{\circ} 24,1993$.

KELLnER, Hans, Language and historical representation, Madison, University of Wisconsin Press, 1989.

KELlEY, D. R., Foundations of modern historical scholarships. Language, law and history in the French renaissance, Nova York, Columbia U. P., 1970.

Koselleck, Reinhart, Futuro pasado. Para una semántica de los tempos históricos, Barcelona - Buenos Aires - México, Ediciones Paidós, 1993.

Koselleck, Reinhart, L'Éxperience de l'histoire, Paris, Gallimard-Seuil, 1997.

KoselleCK, Reinhart, Crítica e crise. Uma contribuição à protogénese do mundo burguês, Rio de Janeiro, Universidade do Estado do Rio de Janeiro, 1999.

Koselleck, Reinhart, historia/Historia, Madrid, Trotta, 2004. 
LANGlois, Charles e SEIGNOBOS, Charles, Introduction aux études historiques, Paris, Hachette, 1898.

LE Goff, Jacques (dir.), La Nouvelle histoire, Paris, Complexe, 2006.

LEDUC, Jean, Les Historiens et le temps, Paris, Seuil, 1999.

Lima, Henrique Espada, A Micro-História. Escalas, indícios e singularidades, Rio de Janeiro, Civilização Brasileira, 2006.

LOSEE, John, Filosofía de la ciencia e investigación histórica, Madrid, Alianza Universidad, 1989.

LoZANO, Jorge, El Discurso histórico, Madrid, Alianza, 1994.

MAnnien, Juha e Toumela, Raino (org.), Ensayos sobre explicación y comprensión, Madrid, Alianza Editorial, 1980.

Marrou, Henri-Irénée, De la Connaissance historique, Paris, Seuil, 1954.

Michelet, Jules, «Préface», Histoire du XIX'̀me siècle, Paris, Germer Baillière, 1872.

MORIN, Edgar, Science avec conscience, Paris, Fayard, 1982.

Mosès, Stéphane, L’Ange de l'histoire. Rosenzweig, Benjamin, Scholem, Paris, Seuil, 1992.

Müller, Bertrand, Correspondance de Marc Bloch et Lucien Febvre, Paris, Fayard, 1994.

MÜLlER, Bertrand (dir.), L'Histoire entre mémoire et épistémologie. Autour de Paul Ricoeur, Lausanne, Éditions Payot Larrousse, 2005.

NieTZSCHE, Sobre a utilidad y el perjuicio de la historia para la vida, Madrid, Biblioteca Nuova, 1999.

NOIRIEL, Gérard, Sur la «crise» de l'histoire, Paris, Belin, 1996.

NOIRIEL, Gérard, Qu'est-ce que l'histoire contemporaine? Paris, Hachette, 1998.

Nora, Pierre e Le Goff, Jacques (org.), Faire de l'histoire, 3 vols., Paris, 1974.

Nora, Pierre (org.), "Préface», Les Lieux de mémoire, vol 1.º, Paris, Gallimard, 1984.

NORA, Pierre (org.), Essais d'ego-histoire, Paris, Gallimard, 1987.

OAKeshotT, Michael, Sobre história e outros ensaios, Rio de Janeiro, Topbooks/Liberty Fund, 2003.

POMIAN, Krzystof, Sur l'histoire, Paris, Gallimard, 1999.

PORTER, Mark, Cultural history and postmodernity, Nova Iorque, Colombia University Press, 1997.

Prost, Antoine, Douze leçons sur l'histoire, Paris, Seuil, 1996.

REISCH, G. A., "Chaos, history and narrative», History and Theory, vol. 30 (1), 1991.

RÉMOND, René, Etre historien aujourd'hui. Travaux du Colloque International, Paris, Érès/Unesco, 1988.

REVEL, Jacques, A Invenção da sociedade, Lisboa, Diffel, 1990.

REVEL, Jacques et al., Jeux d'échelles. La micro-analyse à l'expérience, Paris, Gallimard-Seuil, 1996.

RICKERT, H., Introducción a los problemas de la filosofía de la historia, Buenos Aires, Nova, 1961.

RICKERT, H., Ciencia cultural y ciencia natural, 4a ed., Madrid, Espasa-Calpe, 1965.

RICEUR, Paul, Histoire et vérité, Paris, Seuil, 1955.

RICEeUR, Paul, Temps et récit, 3 vols., Paris, Seuil, 1983.

RiCeEUr, Paul, «Entre mémoire et histoire», Projet, n.o 248, 1996-1997.

RiceEUR, Paul, "La marque du passé», Revue de Métaphysique et de Morale, n. ${ }^{\circ} 1,1998^{\mathrm{a}}$.

RICEUr, Paul, La Mémoire, l'histoire, l'oubli, Paris, Seuil, 2000.

Robin, Régine, Histoire et linguistique, Paris, Armand Colin, 1973.

RORTY, R., El Giro lingüistico, Barcelona, Paidós-UAB, 1990.

Rossi, P., Lo Storicismo tedesco contemporaneo, 9. a ed., Turin, Einaudi, 1971. 
Rossi, P. (ed.), La Teoria della storiografia oggi, México, FCE, 1989.

Ruben, D. H. (ed.), Explanation, Oxford, Oxford University Press, 1993.

RÜSEN, Jörn, «La historia, entre modernidad y postmodernidad», in José Andrés-Gallego (dir.), New History, nouvelle histoire. Hacia una nueva historia, Madrid, Actas, 1993.

SAITTA, A., Guia crítica de historia y historiografia, México, FCE, 1989.

SALMI, Hannu, "On the nature and structure of historical narration", Storia della Storiografia, n. ${ }^{\circ} 24,1993$.

SANTANa PÉRez, JuAn MANuel, "La historia en el fin de una época o el secuestro de Clío», in Barros, Carlos (org.), t. ${ }^{\circ}$ I, Historia a debate, Santiago de Compostela, Historia a Debate, 1995.

SEIGNOBos, Charles, La Méthode historique appliquée aux sciences sociales, Paris, Félix Alcan, 1901.

SeIgnobos, Charles, L'Historien dans l'enseignement secondaire, la méthode, les instruments de travail, Paris, Armand Colin, 1906.

Simiand, François, Méthode historique et sciences sociales, Paris, Éd. Des Archives Contemporaines, 1987.

Simmel, G., Les Problèmes de la philosophie de l'histoire. Une étude d'épistémologie, Paris, PUF, 1984.

SKINNER, Quentin, El Retorno de la gran teoría en las ciencias humanas, Madrid, Alianza Editorial, 1988.

SPIEGEL, Gabrielle M., "Towards a theory of the middle ground: historical writing in the age of posmodernism", in Carlos Barros (org.), Historia a debate (Actas del Congreso "A Historia a debate", celebrado el 7-11 de Julio de 1993 en Santiago de Compostela), tomo I, Santiago de Compostela, Historia a Debate, 1995.

STANFORD, M. J. G., The Nature of historical knowledge, Oxford, Basil Blackwell, 1986.

STAROBINSKI, Jean, «Le mot civilisation», Le Remède dans le mal. Critique et légitimation de l'artifice à l'âge des Lumières, Paris, Gallimard, 1989.

STONE, Lawrence, "The revival of narrative. Reflections on a new old history», Past and Present, n. ${ }^{\circ} 85$, 1979.

STONE, Lawrence, El Pasado y el presente, México, FCE, 1986.

STONe, Lawrence, "History and post-modernism», in Past and Present, n. ${ }^{\circ} 131,1991$.

Stone, Lawrence e SPIEgel, Gabrielle M., "History and post-modernism», in Past and Present, n. ${ }^{\circ} 135$, 1992.

STONE, Lawrence, "The future of history", in Carlos Barros (org.), Historia a Debate (Actas del Congreso "A Historia a debate», celebrado el 7-11 de Julio de 1993 en Santiago de Compostela), tomo I, Santiago de Compostela, Historia a Debate, 1995.

Sutter, Andreas, «Histoire sociale et l'événement historique. Pour une nouvelle approche», Annales, Maio-Junho, n. ${ }^{\circ}$ 3, 1997.

Thompson, E. P., The Voice of the past, Oxford, Oxford University Press, 1978.

Thompson, E. P., Miséria de la teoría, Barcelona, Crítica, 1981.

THUillier, Pierre, Les Savoirs ventriloques ou comment la culture parle à travers la science, Paris, Seuil, 1983.

Tiffenau, D. (ed.), La Narrativité. Recueil préparé sous la direction de ..., Paris, CNRS, 1980.

TOPOLSKY, Jerzy, «Le temps dans le récit historique et les conceptions méthodologiques de l'histoire», Les Cahiers Franco-Polonais, Paris, 1983.

TOPOLSKY, Jersy, «El relato histórico y las condiciones de su validez», Historia y universalidad de las culturas, Barcelona, Seibal/Unesco, 1984.

TOPOLSKY, Jerzy (eds.), Narration and explanations. Contribution to the methodology of historical research, Amsterdam e Atlanta, Ropodi, 1990.

Topolsky, Jerzy, Metodologia de la historia, Madrid, Ed. Cátedra, 1992.

Traverso, Enzo, Le Passé, modes d'emploi. Histoire, mémoire, politique, Paris, La Fabrique Éditions, 2005. 
VANN, Richard T., "Turning linguistic: history and theory and 'History and Theory', 1960-1975», in Frank Ankersmit e Hans Kellner (org.), A New philosophy of history, Londres, Reaktion Books, 1995.

VATTIMO, Gianni, O Fim da modernidade. Niilismo e hermenêutica na cultura pós-moderna, Lisboa, Editorial Presença, 1987.

VeYNe, Paul, Comment on écrit l'histoire, Paris, Seuil, 1979.

VICO, Euvres choisies, Paris, Flammarion, s. d. (selecção e tradução de Jules Michelet).

WHITE, Hayden, Metahistory. The historical imagination in XIX ${ }^{\text {th }}$ century Europe, Baltimore e Londres, The Johns Hopkins University Press, 1978.

WHITE, Hayden, Tropics of discourse. Essays in cultural criticism, Baltimore e Londres, The Johns Hopkins University Press, 1978.

White, Hayden, The Content of the form. Narrative, discourse and historical representation, Baltimore e Londres, The Johns Hopkins University Press, 1987.

WRIGHT, G. H. von, Explicación y compreensión, Madrid, Alianza Editora, 1987. 
Série

Documentos

Imprensa da Universidade de Coimbra

Coimbra University Press

2010

- U

C • 